\title{
Endorphin Massage Efektif Menurunkan Nyeri Punggung Ibu Hamil Trimester III (Di BPM Lulu Surabaya)
}

\author{
Wulan Diana \\ Sekolah Tinggi Ilmu Kesehatan Artha Bodhi Iswara, madielmaheswara@gmail.com
}

\begin{abstract}
Abstrak
Setiap ibu hamil trimester III akan mengalami perubahan fisiologis yang meliputi perubahan fisik dan psikologis. Salah satu perubahan fisik yang terjadi pada ibu hamil trimester III adalah nyeri punggung yang menimbulkan ketidaknyamanan selama kehamilan. Endorphin massage yaitu teknik sentuhan atau pijatan ringan yang dapat memberikan rasa tenang dan nyaman pada ibu hamil yang memasuki usia kehamilan tua dan menjelang persalinan. Tujuan penelitian ini adalah untuk mengetahui keefektifan endorphin massage terhadap penurunan nyeri punggung ibu hamil trimester III di BPM Lulu Surabaya. Rancangan penelitian menggunakan Quasi-Eksperimental dengan menggunakan metode pendekatan one group pre-post test design. Sampel penelitian diambil dengan teknik purposive sampling yaitu 20 ibu hamil trimester III yang mengalami nyeri punggung di BPM Lulu Surabaya. Pengumpulan data dengan menggunakan lembar observasi skala nyeri yang dianalis dengan uji Wilcoxon. Hasil penelitian menunjukkan sebelum diberikan endorphin massage sebagian besar ibu yang mengalami nyeri punggung sedang sebanyak 12 orang (60\%). Setelah diberikan endorphin massage sebagian besar ibu mengalami nyeri punggung ringan yaitu 14 orang $(70 \%)$. Dari hasil analisis menggunakan uji Wilcoxon didapatkan nilai $\rho=0,000<\alpha=$ 0,05 yang menunjukkan bahwa ada keefektifan yang sifnifikan endorphin massage terhadap penurunan nyeri punggung ibu hamil trimester III di BPM Lulu Surabaya. Endorphin massage merupakan pilihan pengobatan non famakologis yang bisa meringankan nyeri punggung ibu hamil trimester III. Sehingga bidan dapat melakukan pelayanan dengan memberikan asuhan kebidanan pada ibu hamil trimester III yang mengalami keluhan nyeri punggung dengan melakukan teknik endorphin massage.
\end{abstract}

Kata kunci: Endorphin Massage, Nyeri Punggung

\begin{abstract}
Every third trimester pregnant woman will experience physiological changes that include physical and psychological changes. One physical change that occurs in pregnant women in the third trimester is back pain that causes discomfort during pregnancy. Endorphin massage is a light touch or massage technique that can provide a sense of calm and comfort in pregnant women who are entering the age of pregnancy and before labor. The purpose of this study was to determine the effectiveness of endorphin massage to reduce back pain in third trimester pregnant women at Lulu Surabaya BPM. The research design uses QuasiExperimental using the one group pre-post test design approach. The research sample was taken by purposive sampling technique, namely 20 trimester III pregnant women who experienced back pain in Lulu Surabaya BPM. Data collection using a pain scale observation sheet analyzed by the Wilcoxon test. The results of the study showed that before given endorphin massage, most of the mothers who had moderate back pain were 12 people (60\%). After being given endorphin massage, most of the mothers experienced mild back pain of 14 people $(70 \%)$. From the results of the analysis using the Wilcoxon test, the value of $\rho=$ $0,000<\alpha=0.05$ showed that there was significant effectiveness of endorphin massage to decrease back pain in third trimester pregnant women at Lulu Surabaya BPM. Endorphin massage is a non famacological treatment option that can relieve back pain in third trimester pregnant women. So that midwives can do services by providing midwifery care to third trimester pregnant women who experience complaints of back pain by doing endorphin massage techniques.
\end{abstract}

Keywords: Endorphin Massage, Back Pain 


\section{PENDAHULUAN}

Setiap wanita hamil akan mengalami berbagai perubahan baik yang terjadi pada trimester I, trimester II dann trimester III, yang meliputi perubahan sistem reproduksi, perkemihan, kardiovaskular, pernafasan, pencernaan, endokrin, imunologi dan muskuloskeletal (Saminem, 2009). Perubahan-perubahan tersebut menimbulkan ketidaknyamanan pada ibu hamil, apalagi kalau kehamilan sudah memasuki usia tua atau trimester III. Salah satu ketidaknyamanan yang dialami ibu hamil trimester III adalah perubahan muskuloskeletal yang menyebabkan nyeri pada punggung ibu (Frazer. D, 2009).

Semakin membesarnya kehamilan, postur tubuh ibu berubah sebagai penyesuaian terhadap uterus yang semakin berat. Nyeri yang dirasakan ibu hamil pada punggung disebabkan oleh karena bahu tertarik kebelakang dan tulang belakang menjadi lebih lengkung, persendian lumbal menjadi lebih elastis sehingga mengakibatkan rasa sakit pada punggung (Fauziah, 2012). Nyeri punggung saat kehamilan disebabkan terjadinya perubahan sruktur anatomis, hormonal dan stress (Andaryono, 2012). Nyeri punggung yang dialami ibu hamil menyebabkan kenyamanan hidup wanita hamil semakin menurun, jika tidak mendapatkan penanganan yang baik (Kartonis et al, 2011).

Menurut Mantle, berdasarkan survey di Inggris dan Skandinavia $50 \%$ ibu hamil menderita nyeri punggung dan $70 \%$ dialami juga pada wanita hamil di Australia. Sehingga latihan fisik yang spesifik diperlukan untuk membantu ibu hamil melakukan adaptasi terhadap perubahan fisik pada tubuhnya selama kehamilan (Brayshaw, 2009). Bedasarkan survey pendahuluan yang dilakukan di BPM Lulu Surabaya, dari 10 ibu hamil yang periksa di BPM Lulu Surabaya, $85 \%$ ibu trimester III mengeluh nyeri punggung yang sangat menganggu kenyamanan dan aktifitasnya sehari-hari. Salah satu usaha yang dilakukan oleh ibu hamil untuk mengobati nyeri punggung tersebut dengan memberikan obat gosok.

Terapi nyeri dapat dilakukan secara farmakologis maupun non farmakologis. Terapi untuk menangani rasa sakit punggung yang dilakukan dengan farmakologis adalah lebih efektif jika dibandingkan dengan terapi non farmakologis, akan tetapi farmakologis lebih expensive dan mempunyai potensi menimbulkan dampak kurang baik pada ibu maupun janin. Sedangkan metode penurunan nyeri non farmakologis bisa dilakukan dengan cara pijatan, sentuhan terapeutik, guide imagery, hydro terahpy, accupresure dan 
akupunktur. Terapi non farmakologis mempunyai keuntungan, yaitu lebih murah, sederhana, efektif dan tidak menimbulkan efek yang merugikan (Potter \& Perry, 2010). Hal tersebut sesuai dengan penelitian yang dilakukan oleh Kurnia, dkk (2017) yaitu sebelum dilakukan intervensi, ibu hamil yang mengalami nyeri ringan sebanyak $8 \%$, nyeri sedang $58 \%$, nyeri berat $35 \%$ sedangkan setelah dilakukan intervensi, ibu hamil yang mengalami nyeri ringan $23 \%$, nyeri sedang $69 \%$ dan nyeri berat 8\%. Hasil uji statistik menunjukkan ada pengaruh yang signifikan intervensi massage dan teknik relaksasi terhadap penurunan tingkat nyeri pada ibu hamil trimester III di klinik Pratama Medika Keluarga Cipinang Jakarta.

Salah satu terapi nyeri secara non farmakologis adalah dengan endorphin massage, yaitu teknik sentuhan atau pijatan ringan yang dapat memberikan rasa tenang dan nyaman pada ibu saat menjelang persalinan maupun saat persalinan berlangsung. Selama ini endorphin sudah dikenal sebagai zat yang banyak manfaatnya (Kuswandi, 2011).

Constance Palinsky adalah seorang ahli kebidanan yang menciptakan endorphin massage yang digunakan untuk mengurangi atau meringankan rasa sakit pada ibu yang akan melahirkan. Rangsangan pada kulit berupa Endorphin massage yang dilakukan pada ibu hamil trimester III yang mengalami nyeri punggung, menggunakan dasar teori pengendalian gerbang pada transmisi nyeri. Teori ini berkembang dari segi mekanisme neurofisiologi yang menyangkut pengontrolan nyeri dari perifer maupun sentral. Menurut teori ini, afferen terdiri dari dua kelompok serabut, yaitu kelompok yang berdiameter besar (A-beta) dan serabut berdiameter kecil (A-delta dan C).

Kedua kelompok afferen ini berinteraksi dengan substansia gelantinosa dan berfungsi sebagai modulator (gerbang kontrol) terhadap Abeta, A-delta dan C. Apabila substansia gelantinosa (SG) aktif, gerbang akan menutup. Sebaliknya apabila SG menurun aktifitasnya, gerbang akan membuka. Aktifitas SG tergantung pada kelompok afferen yang terangsang. B-endorphin menghambat produksi PGE2 melaui jalur siklooksigenase. Peningkatan jumlah $\beta$ endorphin dan penurunan PGE2 memberikan rangsang terhadap non-nociceptive dan hambat nociceptive, sehingga SG aktif dan gerbang kendali menutup.

Berdasarkan uraian di atas peneliti ingin meniliti lebih lanjut tentang keefektifan terapi non farmakologis endorphin massage terhadap penurunan 
nyeri punggung ibu hamil trimester III di BPM Lulu Surabaya.

\section{METODE}

Rancangan penelitian yang digunakan adalah metode penelitian Quasi Eksperiment dengan metode pendekatan one group pre-post test design yaitu : Sebelum diberikan endorphin massage diawali dengan pre test dan setelah diberikan perlakuan, diadakan pengukuran post test (Nasir \& Ideputri, 2011). Populasi dalam penelitian ini adalah semua ibu hamil trimester III di BPM Lulu Surabaya pada Bulan September 2018 sebanyak 20 ibu hamil. Teknik pengambilan sampel adalah dengan total sampling yaitu ibu hamil trimester III yang memenuhi kriteria inklusi, sebanyak 20 orang ibu hamil. Penelitian dilaksanakan di BPM Lulu Surabaya pada Bulan Agustus sampai dengan September 2018.

Prosedur pengumpulan data dengan cara Peneliti memberikan informasi dan minta persetujuan kepada sampel. Instrumen yang digunakan untuk mengukur nyeri adalah dengan kuesioner skala nyeri Numerical Rating Scale (NRS), yang didasari pada skala angka 0-10, yaitu :

0: Tidak ada rasa sakit

1: Sangat ringan, seperti gigitan nyamuk. 2: Nyeri ringan, seperti cubitan pada kulit
3: Nyeri sangat terasa, seperti pukulan ke hidung yang menyebabkan berdarah

4: kuat, nyeri yang dalam, seperti sakit gigi/sengatan lebah

5: Kuat, dalam, nyeri yang menusuk

6: Kuat, dalam, nyeri yang menusuk begitu kuat sehingga sebagian mempengaruhi indra, menyebabkan tidak fokus

7: Rasa sakit yang menusuk kuat menyebabkan tidak dapat berkomunikasi dengan baik dan tidak mampu melakukan perawatan diri

8: Nyeri begitu kuat sehingga tidak lagi dapat berfikir jernih

9: Nyeri begitu kuat sampai menuntut untuk segera menghilangkan rasa sakit dengan cara apapun, tidak peduli apa efek samping atau resikonya

10: Nyeri begitu kuat hingga tak sadarkan diri.

Penilaian skala nyeri dikategorikan menjadi :

0 : Tanpa nyeri

1-3 : Nyeri ringan (nyeri masih bisa ditahan, aktifitas tidak terganggu)

4-6 : Nyeri sedang (mengganggu aktifitas fisik)

7-10 : Nyeri berat (tidak bisa melakukan aktifitas secara mandiri) (Potter \& Perry, 2010)

Endorphin massage dilakukan dengan cara melakukan pijatan ringan yang 
dimulai dari lengan atas kemudian turun menuju lengan bawah yang dilakukan secara perlahan. Kemudian lakukan hal sama pada leher, bahu, punggung dan paha, sementara posisi ibu adalah duduk atau berbaring dan dianjurkan untuk santai. Pijatan ini dilakukan selama 30 menit. Data yang diperoleh berupa tingkat nyeri sebelum diberikan intervensi endorphin massage dibandingkan dengan tingkat nyeri sesudah diberikan intervensi endorphin massage dengan hasil yang diolah dan dianalisis dengan uji Wilcoxon dengan tingkat kepercayaan $95 \%$.

\section{HASIL PENELITIAN}

Tabel 1 Distribusi frekuensi Ibu Hamil Trimester III berdasarkan Usia di BPM Lulu Surabaya

\begin{tabular}{cccc}
\hline No & Usia & Jumlah & Persentase (\%) \\
\hline 1 & $<20$ tahun & 1 & 5,0 \\
2 & $20-35$ tahun & 17 & 85,0 \\
3 & $>35$ tahun & 2 & 10,0 \\
\hline & Jumlah & 20 & 100 \\
\hline
\end{tabular}

Tabel diatas menunjukkan bahwa

Sebagian besar ibu hamil berusia 20-35 tahun yaitu 17 orang $(85,0 \%)$.

Tabel 2 Distribusi frekuensi Ibu Hamil Trimester III berdasarkan Pendidikan di PMB Lulu Surabaya

\begin{tabular}{clcc}
\hline No & Pendidikan & Jumlah & Persentase (\%) \\
\hline 1 & SD & 1 & 5,0 \\
2 & SMP & 5 & 25,0 \\
3 & SMA & 12 & 60,0 \\
4 & Perguruan & 2 & 10,0 \\
& Tinggi & & 100 \\
\hline & Jumlah & 20 & \\
\hline
\end{tabular}

Tabel diatas menunjukkan bahwa sebagian besar ibu hamil mempunyai pendidikan SMA yaitu 12 orang $(60,0 \%)$.

Tabel 3 Distribusi frekuensi Ibu Hamil Trimester III berdasarkan Pekerjaan di PMB Lulu Surabaya

\begin{tabular}{cccc}
\hline No & Pekerjaan & Jumlah & Persentase (\%) \\
\hline 1 & IRT & 13 & 65,0 \\
2 & Karyawati & 4 & 20,0 \\
3 & Wiraswasta & 3 & 15,0 \\
\hline & Jumlah & 20 & 100 \\
\hline
\end{tabular}

Tabel diatas menunjukkan bahwa sebagian besar ibu hamil trimester III adalah ibu rumah tangga yaitu 13 orang $(65 \%)$.

Tabel 4 Distribusi frekuensi Ibu Hamil Trimester III berdasarkan Paritas di PMB Lulu Surabaya

\begin{tabular}{lccc}
\hline No & Paritas & Jumlah & Persentase (\%) \\
\hline 1 & Primipara & 13 & 65,0 \\
2 & Multipara & 7 & 35,0 \\
\hline & Jumlah & 20 & 100 \\
\hline
\end{tabular}

Tabel diatas menunjukkan bahwa sebagian besar ibu hamil trimester III mempunyai paritas primipara yaitu 13 orang $(65,0 \%)$.

Tabel 5 Distribusi frekuensi Tingkat nyeri Ibu Hamil Trimester III sebelum diberikan Endorphin Massage di BPM Lulu Surabaya

\begin{tabular}{clcc}
\hline No & Tingkat Nyeri & Jumlah & $\begin{array}{c}\text { Persentase } \\
(\boldsymbol{\%})\end{array}$ \\
\hline 1 & Tidak nyeri & 0 & 0,0 \\
2 & Nyeri ringan & 3 & 15,0 \\
3 & Nyeri sedang & 12 & 60,0 \\
4 & Nyeri berat & 5 & 25,0 \\
\hline & Jumlah & 20 & 100 \\
\hline
\end{tabular}

Tabel diatas menunjukkan bahwa sebelum diberikan endorphin massage, sebagian 
besar ibu hamil trimester III mengalami nyeri tingkat sedang, yaitu 12 orang $(60 \%)$.

Tabel 6 Distribusi frekuensi Tingkat nyeri Ibu Hamil Trimester III setelah diberikan Endorphin Massage di BPM Lulu Surabaya

\begin{tabular}{cccc}
\hline No & Tingkat nyeri & Jumlah & Persentase (\%) \\
\hline 1 & Tidak Nyeri & 0 & 0,0 \\
2 & Nyeri ringan & 14 & 70,0 \\
3 & Nyeri sedang & 4 & 20,0 \\
4 & Nyeri berat & 2 & 10,0 \\
\hline & Jumlah & 20 & 100 \\
\hline
\end{tabular}

Tabel diatas menunjukkan bahwa setelah diberikan endorphin massage, sebagian besar ibu hamil trimester III mengalami nyeri tingkat ringan, yaitu 14 orang (70\%).

Tabel 7 Perbedaan nyeri sebelum dan setelah di berikan endorphin massage pada ibu Hamil Trimester III di BPM Lulu Surabaya

\begin{tabular}{llllll}
\hline $\begin{array}{l}\text { Vari } \\
\text { abel }\end{array}$ & $\begin{array}{l}\text { Perlaku } \\
\text { an }\end{array}$ & n & Mean & SD & p-value \\
\hline Nyeri & Sebelum & 20 & 2,10 & 0,64072 & 0,000 \\
& Sesudah & 20 & 1,40 & 0,68056 & \\
& & & & &
\end{tabular}

Berdasarkan tabel diatas dapat diketahui bahwa rata-rata tingkat nyeri sebelum diberikan endorphin massage sebesar 2,10 dan Setelah diberikan endorphin massage turun menjadi 1,40

Hasil uji statistik dengan menggunakan uji Wilcoxon dengan tingkat kemaknaan $\alpha$ $=0,05$ dengan dilakukan perhitungan SPSS didapatkan hasil $p=0,000$. Jika dibandingkan dengan $\alpha$, diperoleh $p$ $(0,000)<\alpha(0,05)$, sehingga dapat dikatakan bahwa ada perbedaan nyeri punggung pada ibu hamil trimester III antara sebelum dan sesudah diberikan endorphin massage. Hal ini berarti bahwa ada pengaruh endorphin massage terhadap nyeri punggung ibu hamil trimester III di BPM Lulu Surabaya.

\section{PEMBAHASAN}

1. Analisis nyeri punggung pada ibu hamil trimester III sebelum diberikan endorphin massage di BPM Lulu Surabaya.

Berdasarkan hasil penelitian menunjukkan bahwa sebelum diberikan endorphin massage sebagian besar ibu hamil trimester III mengalami nyeri punggung sedang yaitu 12 orang(60\%).

Pada kehamilan tua, postur tubuh wanita mengalami perubahan untuk mengkompensasi berat uterus yang sedang tumbuh. Menurut Varney (2007) nyeri punggung terjadi karena semakin besarnya umur kehamilan. Semakin besar kehamilan bisa menyebabkan meningkatnya beban uterus sehingga terjadi regangan di punggung ibu hamil. Pertambahan berat badan selama kehamilan menyebabkan tulang yang berfungsi untuk menopang tubuh akan mengalami gangguan. Postur tubuh ibu juga akan berubah sebagai kompensasi bertambahnya umur kehamilan. Hal ini yang menyebabkan nyeri 
Wulan Diana 68 Endorphin Massage Efektif Menurunkan Nyeri Punggung Ibu Hamil Trimester III (Di BPM Lulu Surabaya)

punggung yang dialami pada ibu hamil (Rukiyah dkk, 2009).

Hasil penelitian ini sebagian besar ibu hamil trimester III mengalami nyeri punggung sedang yaitu $60 \%$ dibanding dengan ibu yang mengalami nyeri punggung ringan yaitu $15 \%$. Menurut Faser (2009), nyeri pungung bisa terjadi jika ibu hamil mengangkat objek berat yang mengakibatkan terjadinya ketegangan otot panggul. Semua gerakan berbahaya yang tidak boleh dilakukan adalah semua gerakan berputar sambil mengangkat beban. Hal ini sesuai hasil penelitian bahwa sebagian besar pekerjaan ibu adalah ibu rumah tangga, yaitu 13 orang $(65 \%)$.

Menurut wawancara yang dilakukan kepa ibu hamil trimester III, banyak tugas rumah tangga yang harus mereka lakukan di rumah, seperti menyeterika, menyapu, menyiapkan makanan dengan posisi berdiri dalam waktu yang lama. Hal ini akan meningkatkan kejadian nyeri punggung pada ibu hamil trimester III.

2. Analisis nyeri punggug pada ibu hamil trimester III sesudah diberikan endorphin massage di BPM Lulu Surabaya.

Berdasarkan hasil penelitian menunjukkan bahwa sesudah diberikan endorphin masage jumlah ibu hamil trimester III yang mengalami nyeri punggung ringan sebagian besar yaitu 14 ibu hamil (70\%).

Endorphin massage merupakan terapi sentuhan/pijatan ringan yang perlu dilakukan untuk ibu hamil diakhir kehamilan maupun pada saat melahirkan. Hal tersebut dikarenakan sentuhan/pijatan ringan akan memicu tubuh mengeluarkan endorphin sebagai senyawa yang bisa meringankan rasa nyeri dan menimbulkan rasa nyaman (Kuswandi, 2011). Hal ini didukung oleh penelitian Catur dkk (2017), yaitu ibu hamil yang diberi terapi endorphin massage sebagian besar mengalami penurunan skala nyeri. Terapi endorphin massage membuat ibu mengalami nyaman dan relaks.

Berdasarkan hasil penelitian terdapat peningkatan jumlah ibu hamil trimester III yang mengalami nyeri ringan setelah diberikan endorphim massage, sebaliknya ibu hamil yang mengalami nyeri sedang mengalami penurunan setelah diberikan endorphin massage. Hal ini disebabkan karena rangsangan di permukaan kulit yang berupa teknik endorphin massage menghasilkan impuls yang dikirim melalui serabut saraf besar di permukaan kulit. Rangsangan ini memblokir serabut saraf besar yang mengakibatkan pesan nyeri tidak diterima oleh otak, hal ini mengakibatkan perubahan terhadap persepsi nyeri. Disamping itu, massage ini 
bisa menurunkan otot yang tegang serta menambah sirkulasi darah di daerah yang nyeri, sehingga bisa untuk mengurangi rasa sakit yang dirasakan oleh wanita hamil yang memasuki usia kehamilan trimester III.

3. Efektifitas endorphin massage untuk menurunkan nyeri punggung ibu hamil trimester III di BPM Lulu Surabaya.

Berdasarkan uji statistik Wilcoxon diperoleh hasil $p$-value $=0,000$ dan nilai $\alpha$ $=0,05$. Maka $p<\alpha$ sehingga dapat disimpulkan bahwan ada perbedaan yang signifikan nyeri punggung sebelum dan sesudah diberikan endorphin massage pada ibu hamil trimester III di BPM Lulu Surabaya. Nilai rata-rata skala nyeri sebelum diberikan endorphin massage adalah sebesar 2,10, sesudah diberikan endorphin massage turun menjadi 1,40. Hal ini menunjukkan ada keefektifan yang signifikan endorphin massage terhadap penurunan nyeri punggung pada ibu hamil trimester III di BPM Lulu Surabaya.

Endorphin merupakan gabungan endogen dan morphine, yaitu zat yang didalam tubuh yang merupakan unsur dari protein yang diproduksi oleh sel-sel tubuh serta sistem saraf manusia. Endorphin dalam tubuh munculnya bisa dipicu dengan berbagai cara yaitu pernafasan dalam, sentuhan atau pijatan serta meditasi. Endorphin massage merupakan teknik sentuhan dan pijatan pada ibu hamil. Teknik ini dapat membantu memberikan rasa tenang dan nyaman disaat maupun menjelang persalinan. Hal tersebut disebabkan karena pijatan merangsang tubuh untuk melepaskan senyawa endorphin yang merupakan pereda rasa sakit dan dapat menimbulkan perasaan nyaman (Irawati, 2018). Endorphin dianggap sebagai zat penghilang rasa sakit yang terbaik karena bisa diproduksi oleh tubuh manusia sendiri.

Hasil analisis diatas menyebutkan bahwa endorphin massage sangat efektif untuk mengurangi nyeri punggung ibu hamil trimester III. Karena endorphin massage mempunyai efek nonfarmakologis untuk menurunkan nyeri saat dan menjelang persalinan yang tidak membahayakan bagi ibu maupun janin.

\section{SIMPULAN}

Endorphin massage efektif untuk menurunkan nyeri punggung ibu hamil trimester III di BPM Lulu Surabaya.

\section{REFERENSI}

Andarmoyo, Sulistyo. 2013. Konsep \& Proses Keperawatan Nyeri. Jogjakarta. Ar-ruzz Medika

Arikunto, 2006. Manajemen Penelitian. Jakarta. Bumi Aksara.

Bobak, L. Jensen. 2004. Buku Ajar Keperawatan Maternitas. Jakarta. EGC. 
Brayshaw, E. 2009. Latihan fisik khusus Selama kehamilan dan Masa NifasIn P.Karyuni, L. Mahmudah \& F. Ariani, eds. Buku Ajar BidanMyles. Jakarta. EGC

Catur, dkk. 2017. Endorphin Massage Untuk Menurunkan Intensitas Nyeri Kala I Fase Aktif Persalinan di Puskesmas Kabupaten Demak. Jurnal SMART volume 4 No 2.

Fauziah, Siti. 2012. Buku Ajar Keperawatan Maternitas Kehamilan volume I. Jakarta. Kencana.

Fraser, D. 2009. Buku Ajar Bidan. Jakarta. EGC. Henderson, Christine \& Katheleen Jones. 2010. Buku Ajar Konsep Kebidanan. Jakarta. EGC.

Irawati, 2018. Pengaruh Endorphin Massage Terhadap Rasa Nyaman Selama Proses Persalinan di Puskesmas Kabupaten Luwu Timur.

Kartonis et al. 2011. Pregnancy-Related Low Back Pain. 15 (3). PP-10. Hippokratia

Kurnia, dkk. 2017. Hubungan Efektifitas massage dan teknik relaksasi dengan pengurangan Nyeri Punggung pada kehamilan trimester III di klinik pratama Keluarga medika Jakarta. Jurnal khusus FIK volume 40 No 57

Kuswandi. 2011. Asuhan Kebidanan: Persalinan \& Kehamilan. Jakarta. EGC.

Mandriwati, GA, 2011. Asuhan Kehamilan Antenatal. Jakarta. EGC.

Manuaba, I.B.G. 2007. Pengantar Kuliah Obstetri. Jakarta. EGC.

Nasir, Muhith \& Ideputri. 2011. Metodologi penelitian. Yogyakarta. Maha Medika.

Rukiyah, dkk. 2009. Perawatan Ibu Hamil. Yogyakarta. Panji Pustaka.

Saminem. 2009. Buku Saku Kebidanan. Jakarta. EGC.
Sugiono. 2007. Statistika Untuk Penelitian. Bandung. Alphabeta.

Potter \& Pery. 2010. Fundamental Keperawatan (edisi 7 volume 2). Jakarta. Salemba.

Varney, Helen. 2007. Asuhan Antenatal. Jakarta. EGC.

Varney, Helen. 2011. Buku AjarAsuhan Kebidanan Edisi 4.Jakarta. EGC. 